\title{
Speciation of iodine isotopes inside and outside of a contaminant plume at the Savannah River Site
}

\author{
Kathleen A. Schwehr ${ }^{2 *}$, Shigeyoshi Otosaka ${ }^{1,2}$, Silke Merchel $^{3}$, Daniel I. Kaplan ${ }^{4}$, Saijin \\ Zhang $^{2}$, Chen $\mathrm{Xu}^{2}$, Hsiu-Ping $\mathrm{Li}^{2}$, Yi-Fang $\mathrm{Ho}^{2}$, Chris M. Yeager ${ }^{5}$, ASTER Team ${ }^{6}$, Peter H. \\ Santschi ${ }^{2}$
}

${ }^{1}$ Research Group for Environmental Science, Japan Atomic Energy Agency, Tokai-Mura, Ibaraki 319-1195, Japan

${ }^{2}$ Laboratory for Oceanographic and Environmental Research, Department of Marine Sciences, Texas A\&M University, OCSB 3029, 200 Seawolf Parkway, Galveston, TX 77553, United States

${ }^{3}$ Helmholtz-Zentrum Dresden-Rossendorf, Bautzner Landstraße 400, 01328 Dresden, Germany (s.merchel@hzdr.de)

${ }^{4}$ Savannah River National Laboratory, Aiken, SC 29808, United States

${ }^{5}$ Los Alamos National Laboratory, Los Alamos, NM 87545, United States

${ }^{6}$ Maurice Arnold, Georges Aumaître, Didier L. Bourlès, Karim Keddadouche, Aix-Marseille University, CEREGE, CNRS-IRD UM 34, 13545 Aix-en-Provence, France

${ }^{*}$ Corresponding author

Phone: 409-740-4530

Facsimile: 409-740-4787

e-mail: schwehrk@tamug.edu

(C) 2014. This manuscript version is made available under the Elsevier user license http://www.elsevier.com/open-access/userlicense/1.0/ 


\begin{abstract}
A primary obstacle to understanding the fate and transport of the toxic radionuclide ${ }^{129} \mathrm{I}$ (a thyroid seeker) is an accurate method to distinguish it from the stable isotope, ${ }^{127} \mathrm{I}$, and to quantify the various species at environmentally relevant concentrations $\left(\sim 10^{-8} \mathrm{M}\right)$. A $\mathrm{pH}$-dependent solvent extraction and combustion method was paired with accelerator mass spectrometry (AMS) to measure ambient levels of ${ }^{129} \mathrm{I} /{ }^{127} \mathrm{I}$ isotope ratios and iodine speciation (iodide $\left(\mathrm{I}^{-}\right)$, iodate $\left(\mathrm{IO}_{3}{ }^{-}\right)$, and organo-I $(\mathrm{OI})$ ) in aquatic systems. The method exhibited an overall uncertainty of $10 \%$ or less for $\mathrm{I}^{-}$and $\mathrm{IO}_{3}{ }^{-}$, and less than $30 \%$ for OI species concentrations and enabled ${ }^{129}$ I measurements as low as $0.001 \mathrm{~Bq} / \mathrm{L}\left(1 \mathrm{~Bq} / \mathrm{L}=10^{-13} \mathrm{M}\right)$. The method was used to analyze groundwater from the Savannah River Site (SRS), South Carolina, USA, along a $\mathrm{pH}$, redox potential (Eh), and organic carbon gradient (8-60 uM DOC). The data confirmed that the ${ }^{129} \mathrm{I} /{ }^{127} \mathrm{I}$ ratios and species distribution were strongly $\mathrm{pH}$ dependent and varied in a systematic manner from the strongly acidic source. While ${ }^{129} \mathrm{I}$ speciation in plume samples containing total I concentrations $>1.7 \mathrm{~Bq} / \mathrm{L}$ were similar whether measured by AMS or GC-MS $\left(\left[\mathrm{I}^{-}\right] \gg\left[\mathrm{IO}_{3}{ }^{-}\right]=[\mathrm{OI}]\right)$, AMS enabled ${ }^{129}$ I speciation measurements at much lower concentrations than was possible with the GC-MS. AMS analyses demonstrated that groundwater samples minimally impacted by the plume were still orders of magnitude higher than ambient ${ }^{129}$ I concentrations typically found elsewhere in the USA groundwaters and rivers. This is likely due to past atmospheric releases of volatile ${ }^{129} \mathrm{I}$ species by SRS nuclear reprocessing facilities near the study site. Furthermore, the results confirmed the existence of ${ }^{129} \mathrm{I}$ as not only $\mathrm{I}^{-}$, but also as $\mathrm{OI}$ and $\mathrm{IO}_{3}{ }^{-}$species.
\end{abstract}




\section{Introduction}

Radioiodine $\left({ }^{129} \mathrm{I}\right.$ : half-life $=(1.57 \pm 0.04) \times 10^{7} \mathrm{a}$, (Emery et al., 1972) $)$ is naturally produced by cosmic ray bombardment of ${ }^{130} \mathrm{Te}$ and atmospheric xenon isotopes, as well as spontaneous nuclear fission of primordial uranium in the earth's crust. However, most ${ }^{129} \mathrm{I}$ in the surface environment originates from nuclear fuel reprocessing plant emissions and nuclear weapons testing. These sources have increased the concentration of ${ }^{129} \mathrm{I}$ in aquatic systems by as much as three orders of magnitude above natural levels $\left(\sim 7.5 \times 10^{-11} \mathrm{~Bq} / \mathrm{L}\right)$ and raised the natural isotopic ratio as much as 5 orders of magnitude above the natural ratio $\left({ }^{129} \mathrm{I} /{ }^{127} \mathrm{I}=1.5 \times 10^{-12}\right)$ in the last few decades (Santschi and Schwehr, 2004; Snyder and Fehn, 2004; Hou et al., 2008). Hou and Hou (2012) have provided a review of sources and concentrations of ${ }^{129} \mathrm{I}$ and ${ }^{129} \mathrm{I} / \mathrm{I}$ ratio values in the environment. The Fukushima Daiichi Nuclear Power Plant accident reportedly introduced $\sim 1.2 \mathrm{~kg}$ of ${ }^{129} \mathrm{I}$ into the environment (Hou et al., 2013), and the Chernobyl accident introduced $\sim 1.3-6 \mathrm{~kg}$ of ${ }^{129} \mathrm{I}$ into the environment. However, ${ }^{129}$ I releases from these well-known nuclear incidents are relatively small compared to the amount released into the environment from ongoing nuclear fuel reprocessing in France and England, where approximately 5600 and $255 \mathrm{~kg}$ of ${ }^{129} \mathrm{I}$ has been released into the ocean and atmosphere, respectively, through 2008 (Hou and Hou, 2012).

In this study, we develop more insight as to how the ${ }^{129} \mathrm{I}$ contamination at the nuclear separation facility at the U.S. Department of Energy Savannah River Site (SRS) F-Area fits into the global picture. It is our intent to demonstrate that management of the radionuclide waste at this facility should be an ongoing consideration. Past operations at the SRS F-Area nuclear separation facility resulted in the release of multiple radionuclides into the environment, including ${ }^{3} \mathrm{H},{ }^{129} \mathrm{I},{ }^{90} \mathrm{Sr},{ }^{239} \mathrm{Pu},{ }^{235} \mathrm{U}$, and ${ }^{238} \mathrm{U}$ (Savannah River Nuclear Solutions, 2008). Unlined seepage basins associated with the facility routinely received acidic (average $\mathrm{pH}=2.3$ ), radionuclide-contaminated wastewaters between 1955 and 1988 (Kaplan et al., 2011; Savannah River Nuclear Solutions, 2008). The seepage basins were closed in 1988 by removing the bottom layer of highly contaminated sediment, and adding limestone and blast furnace slag (a sulfide based by-product recovered from iron ore 
processing) to immobilize heavy metals (including $\mathrm{Hg}, \mathrm{Pb}, \mathrm{Cd}, \mathrm{Cr}$, and $\mathrm{As}$ ) and multi-valent radionuclides (e.g., ${ }^{241} \mathrm{Am},{ }^{141 \& 144} \mathrm{Ce},{ }^{244} \mathrm{Cm},{ }^{238 \& 239} \mathrm{Pu},{ }^{90} \mathrm{Sr}$ and ${ }^{235 \& 238} \mathrm{U}$ ). The basins were capped in 1991 with a low permeability engineered barrier system to reduce downward migration of radionuclides into the groundwater. In addition, since 2005, a base-injection/funnel-and-gate remediation program was established $300-500 \mathrm{~m}$ down gradient from the primary seepage basin. These remediation efforts have led to the effective immobilization of most radionuclides and heavy metal contaminants (Dai et al., 2002). However, the rising $\mathrm{pH}$ of the groundwater over the last 19 years due to the remedial base injection and the basin closure with limestone has been shown to be partially responsible for the remobilization of ${ }^{129} \mathrm{I}$ from the seepage basins and aquifer sediments, resulting in groundwater concentrations increasing from 7.4 to $37 \mathrm{~Bq} / \mathrm{L}{ }^{129} \mathrm{I}$ (the Environmental Protection Agency's (EPA) maximum contaminant level (MCL) is $0.037 \mathrm{~Bq} / \mathrm{L}(1 \mathrm{pCi} / \mathrm{L}))$ (Kaplan et al., 2011).

In aquatic systems iodine occurs in three chemical forms - iodide ( $\left.\mathrm{I}^{-}\right)$, iodate $\left(\mathrm{IO}_{3}{ }^{-}\right)$ and organo-iodine (OI) - whose proportions vary as a function of biogeochemical properties in the aquatic system, including $\mathrm{pH}$, redox state (Eh), dissolved organic carbon (DOC) concentrations, and microbial processes (Hou et al., 2008; Schwehr et al., 2005; Lehto et al., 2012; Xu et al., 2011a, b; Kaplan et al., 2013). The ${ }^{129}$ I speciation and concentrations in groundwater from SRS F-Area were found to vary as a function of: 1) proximity to the source term (the seepage basins), 2) $\mathrm{pH}, 3$ ) Eh, and 4) proximity to the high-organic matter wetland that receives the ${ }^{129}$ I plume (Otosaka et al., 2011).

Most importantly, ${ }^{129}$ I partitioning to the aquifer solid phase was found to be influenced by I concentration (Schwehr et al., 2009; Zhang et al., 2010, 2011), pH (Kaplan et al., 2013), redox potential (Emerson et al., 2014), sediment organic matter (SOM) concentrations (Xu et al., 2011a, b), and microbial activity (Li et al., 2012). These studies have consistently demonstrated the necessity of studying I biogeochemistry at environmentally relevant concentrations (10's to 100 's Bq/L) to avoid experimental artifacts associated with I speciation, partitioning to sediments, and complexation with naturally occurring aqueous and solid phase organic carbon (Schwehr et al., 2009; Xu et al., 2011a, b; 
Zhang et al., 2011).

In our previous studies of SRS groundwater, ${ }^{129}$ I and ${ }^{127}$ I speciation was determined by a gas chromatography-mass spectrometry (GC-MS) method (Zhang et al., 2010). This method is very useful because it only requires small sample volumes $(\sim 5 \mathrm{~mL})$, and it is relatively fast, simple, and inexpensive. Additionally, both isotopes can be measured simultaneously. This GC-MS method has been used to simultaneously measure ${ }^{129} \mathrm{I}$ and ${ }^{127} \mathrm{I}$ speciation and isotopic ratios in groundwater collected from the ${ }^{129} \mathrm{I}$-contaminated F-Area plume (Otosaka et al., 2011). However, although Zhang et al. (2010) reports a detection limit of $0.08 \mathrm{~Bq} / \mathrm{L}$, it is difficult to measure complete ${ }^{129} \mathrm{I}$ speciation at levels below $0.5 \mathrm{~Bq} / \mathrm{L}$, such as found in groundwater outside of the ${ }^{129}$ I plume. As a consequence, little is known about ${ }^{129}$ I species outside or along the boundaries of plumes, where contamination levels are relatively low.

Since the 1980s, accelerator mass spectrometry (AMS) has been recognized as the most reliable analytical method for ${ }^{129} \mathrm{I}$ and has been used for measurements of natural-levels of ${ }^{129} \mathrm{I}$ in environmental samples (e.g., Fabryka-Martin et al., 1985; Schink et al., 1995; Santschi et al., 1996; Moran et al., 1999; Schwehr et al., 2005; Suzuki et al., 2009). Detection limits of AMS are orders of magnitude lower than that of GC-MS and lower than those of radiochemical neutron activation analysis (RNAA) (Szidat et al., 2000) and inductively coupled plasma-mass spectrometry (ICP-MS) (Hou et al., 2008; Murumatsu et al., 2008). Even though analysis of ${ }^{129}$ I species in aquatic samples has been performed using AMS, existing speciation separation techniques are complicated, employing ion exchange chromatographic resins and dehydrohalogenation of OI, and typically require solvent extractions (e.g., Schwehr et al., 2005).

In this study, we used the GC-MS method of Zhang et al. (2010) to analyze ${ }^{129} \mathrm{I}$ concentration and speciation levels within the SRS F-area plume, and AMS to determine ${ }^{129} \mathrm{I}$ concentration and speciation where I concentrations are near or below the detection limits of the GC-MS. The I species were determined by AMS after selective extraction into an organic phase controlled by $\mathrm{pH}-$ and oxidant strength, similar to the method of Hou et al., 2009, with the exception that their treatment of Total I (TI) and OI are different. 
The hypothesis of this study was that the distribution of iodine species would remain largely similar at $10^{-9}-10^{-11} \mathrm{M}$ (GC-MS detectable levels) and $<10^{-12} \mathrm{M}$ (AMS detectable levels) because key sediment properties influencing iodine speciation are similar and at environmentally relevant concentrations. Key objectives of this study included the determination of the speciation of ${ }^{129} \mathrm{I}$ in groundwater, to delineate the general distribution of ${ }^{129}$ I species in the system, which required a comparison of the GC-MS method of Zhang et al. (2010) with low-level AMS measurements. Another key question was to determine if the biogeochemical behavior of I species was different at sub Bq/L concentrations (AMS concentrations) as compared to $\mathrm{Bq} / \mathrm{L}$ concentrations (GC-MS).

\section{Materials and methods}

All chemicals used in this study were analytical grade or equivalent. The $\mathrm{I}^{-}$and $\mathrm{IO}_{3}{ }^{-}$ salts were purchased from Fluka Chemicals (St. Louis, MO), and the other reagents were purchased from Fisher Scientific (Pittsburgh, PA). Reagent solutions were prepared in de-ionized water of 18.2 M $\Omega$ resistance produced from a Barnstead NANOpure system. The back extraction (BE) solution consisted of a mixture of $0.1 \mathrm{M}$ sulfite and $0.18 \mathrm{M}$ of sulfuric acid. The reduction solution (RS) was a 2:1 mixture of $1 \mathrm{M}$ hydroxylamine hydrochloride and 1M sodium sulfite. A schematic of the following methods is shown as Fig. S1.

\subsection{1. ${ }^{129} I /{ }^{127}$ I-Iodide}

The sample preparation protocol for I speciation, extraction, and precipitation (Fig. S1) does not require the use of ion exchange or chelating resins, thereby reducing the risk of sample contamination. Furthermore, this method has the advantage that it can be used to process a wide range of environmental aquatic sample volumes, $50-1000 \mathrm{~mL}$. The procedure calls for three subsamples to be prepared and analyzed individually for $\mathrm{I}^{-}$, total inorganic $\mathrm{I}\left(\mathrm{I}^{-}\right.$and $\left.\mathrm{IO}_{3}{ }^{-}\right)$, and total $\mathrm{I}_{(}\left(\mathrm{I}^{-} \mathrm{IO}_{3}{ }^{-}\right.$, and $\left.\mathrm{OI}\right)$. Therefore $\mathrm{I}^{-}$is measured directly, and $\mathrm{IO}_{3}{ }^{-}$and $\mathrm{OI}$ are calculated by difference. To separate, purify, and concentrate the $\mathrm{I}^{-}$species from other aqueous ions the following procedure was followed. After removal of suspended 
particles with a $0.45 \mu \mathrm{m}$ polycarbonate filter, $2 \mathrm{mg}$ of $\mathrm{I}^{-}$carrier was added to $50-1000 \mathrm{~mL}$ of the aquatic sample, and the $\mathrm{pH}$ was adjusted to 4 - 6 using $0.1 \mathrm{M} \mathrm{HNO}_{3}$ or $0.1 \mathrm{M} \mathrm{NaOH}$ (Fig. S1). Following the method of Schwehr et al. (2005), samples were then transferred to a separation funnel containing $10-40 \mathrm{~mL}$ of chloroform $\left(\mathrm{CHCl}_{3}\right)$. Next, $0.2 \%$ sodium hypochlorite $(10 \mathrm{~mL}$ per $1 \mathrm{~L}$ of sample) was gently mixed into the sample and allowed to react for 10 minutes to oxidize $\mathrm{I}^{-}$to molecular $\mathrm{I}\left(\mathrm{I}_{2}\right)$. The mixture was then shaken to extract the evolving $\mathrm{I}_{2}$ into the $\mathrm{CHCl}_{3}$ solvent. This oxidation/extraction process was repeated four times to ensure complete oxidation of $I^{-}$. The solvent solutions containing $I_{2}$ were then pooled and transferred to a different separation funnel. Next, $30 \mathrm{~mL}$ of BE was added to reduce $\mathrm{I}_{2}$ to $\mathrm{I}^{-}$, which partitions into the aqueous phase. After shaking and venting, the aqueous phase $(\sim 30 \mathrm{~mL})$ was transferred to a $50 \mathrm{~mL}$ polypropylene centrifuge tube.

$\mathrm{I}^{-}$in the aqueous phase was precipitated as silver iodide (AgI) by adding $1 \mathrm{~mL}$ of $1 \mathrm{M}$ silver nitrate. AgI was purified with successive washes of deionized water, $30 \% \mathrm{v} / \mathrm{v}$ ammonia (to dissolve $\mathrm{AgCl}$ ), and methanol (to remove trace organic solvent and to promote drying of the precipitate). The purified AgI was then dried, mixed with silver powder (Aldrich, <325 mesh, 99.99\%) in a 1:2 weight ratio AgI:Ag, and pressed into a specialized copper target holder (Arnold et al., 2013) for AMS measurements of the ${ }^{129} \mathrm{I} /{ }^{127} \mathrm{I}$ ratio (see below). Then, for each sample, the ${ }^{129} \mathrm{I}^{-}$concentration was calculated from the AMS ${ }^{129} \mathrm{I}^{127} \mathrm{I}$ ratio by multiplying the sum of the concentration of ${ }^{127} \mathrm{I}^{-}$in the sample that was measured independently by GC-MS plus the ${ }^{127} \mathrm{I}$ in the added carrier.

\subsection{2. ${ }^{129} I /{ }^{127}$ I-Iodate}

Iodate concentrations were estimated by measuring the total inorganic I (TII) fraction and then subtracting the previously measured $\mathrm{I}^{-}$fraction $\left(\left[\mathrm{IO}_{3}^{-}\right]=[\mathrm{TII}]-\left[\mathrm{I}^{-}\right]\right)($Fig. S1). After the removal of suspended particles with a $0.45 \mu \mathrm{m}$ polycarbonate filter, $2 \mathrm{mg}$ of $\mathrm{I}^{-}$ carrier and RS (6 mL per $1 \mathrm{~L}$ of sample) were added to $50-1000 \mathrm{~mL}$ of the aqueous sample, converting $\mathrm{IO}_{3}{ }^{-}$to $\mathrm{I}^{-}$(Zhang et al., 2010). After allowing 60 minutes for reaction time, the sample was transferred to a separation funnel with $10-40 \mathrm{~mL}$ of chloroform. The solution was adjusted to $\mathrm{pH}<2$ by adding $6 \mathrm{M}$ nitric acid. A $1 \%$ sodium hypochlorite $(\mathrm{NaClO} ; 10 \mathrm{~mL}$ 
per $1 \mathrm{~L}$ of sample) amendment was then added to convert $\mathrm{I}^{-}$to $\mathrm{I}_{2}$. The $\mathrm{I}_{2}$ was extracted into the chloroform organic solvent phase by shaking and venting. The organic solvent was removed and temporarily stored in a Teflon bottle. This extraction process was repeated 4 times for complete extraction. The resultant $\mathrm{I}_{2}$ organic solutions were pooled. I in the organic solvent was then back-extracted, precipitated as silver $\mathrm{I}^{-}$, and the precipitate was further purified using the same procedure as described for $\mathrm{I}^{-}$above.

The ${ }^{129} \mathrm{I} /{ }^{127} \mathrm{I}$ isotopic ratio for TII in silver $\mathrm{I}^{-}$was measured by AMS. Then, for each sample, the ${ }^{129} \mathrm{I}$-TII concentration was calculated by multiplying the ${ }^{129} \mathrm{I} /{ }^{127} \mathrm{I}$ ratio for TII by the sum of the ${ }^{127}$ I-TII concentration in the sample that was measured independently by GC-MS plus the ${ }^{127} \mathrm{I}$ carrier. The ${ }^{129} \mathrm{IO}_{3}{ }^{-}$concentration was calculated by subtracting the ${ }^{129} \mathrm{I}^{-}$ concentration from the ${ }^{129}$ I-TII concentration.

\subsubsection{Organo- ${ }^{129} \mathrm{I}^{127} I$}

Organo- ${ }^{129}$ I was calculated by subtracting ${ }^{129}$ I-TII from the total ${ }^{129}$ I concentration (for ${ }^{129} \mathrm{I}:[\mathrm{OI}]=[\mathrm{TI}]-[\mathrm{TII}]$ ). Total I (TI) in the aqueous sample was determined by combustion and trapping the iodine in deionized water using the method of Zhang et al. 2010. Briefly, $\sim 5 \mathrm{~mL}$ of the aqueous sample was mixed with $100 \mathrm{mg}$ vanadium pentoxide and combusted in a quartz tube at $200{ }^{\circ} \mathrm{C}$ for $8 \mathrm{~min}$, then $900{ }^{\circ} \mathrm{C}$ for $10 \mathrm{~min}$. The combusted TI was collected in a glass tube containing 1- $2 \mathrm{~mL}$ of deionized water. Oxygen gas was used as a carrier at a flow rate of $150-200 \mathrm{~mL} / \mathrm{min}$. The receiving solution was then diluted with 30 $\mathrm{mL}$ of deionized water. This combustion method was validated by Zhang et al. (2010), using $\sim 100 \mathrm{~Bq}^{125} \mathrm{I}^{-}$as a recovery tracer for $\mathrm{I}^{-}, \mathrm{IO}_{3}^{-}$, and thyroxine (an OI compound), with recovery rates $>90 \%$ (Zhang et al., 2010). The I in the receiving solution was extracted, purified, and precipitated as AgI, using the same procedure as described above for ${ }^{129} \mathrm{I}-\mathrm{TII}$.

\subsection{Determination of the ${ }^{129} I /^{127}$ I Ratio by AMS}

Measurement of ${ }^{129} \mathrm{I} /{ }^{127} \mathrm{I}$ ratios were carried out at the French AMS National Facility ASTER (CEREGE, Aix-en-Provence). Detailed conditions for the AMS measurements are described in Arnold et al. (2010, 2013). Briefly, the tandem accelerator 
voltage was set to $5 \mathrm{MV}$ and ions with charge state 5+ were selected for analysis. Special precautions with respect to cross-contamination were taken, such as selecting the optimal ion source conditions (target voltage: $3.5 \mathrm{kV}$; extraction voltage: $26 \mathrm{kV}$ ). The ion source was cleaned between each sample by sputtering the carbon targets for 5 min each. All samples were divided into two batches that were measured on separate days. Each unknown sample, blank, standard, and quality assurance sample was measured three times. Measurements proceeded for a maximum of 30 min until uncertainties (emanating solely from AMS instrumental measurement) of $0.8-2.2 \%$ were reached for both samples and standards.

${ }^{129} \mathrm{I} /{ }^{127} \mathrm{I}$ isotopic ratios were normalized to in-house standard material SM-I-10 $\left({ }^{129} \mathrm{I} /{ }^{127} \mathrm{I}=(1.064 \pm 0.014) \times 10^{-10}\right)$, which is directly traceable to the primary standard reference material NIST $3231\left({ }^{129} \mathrm{I} /{ }^{127} \mathrm{I}=(0.982 \pm 0.012) \times 10^{-8}\right)$ by cross-calibration (Arnold et al., 2013). For the purpose of blank correction, the deionized water was processed in a manner identical to the processing of the samples. The ${ }^{129} \mathrm{I}$ amount in the blank AgI was subtracted from those in the sample AgI. Since the procedures were different between I species, blank corrections were made for each species with the corresponding blank AgI target. The ${ }^{129} \mathrm{I} /{ }^{127} \mathrm{I}$ ratios for the blanks were at least an order of magnitude $\left(10^{-12}\right)$ lower than the measured ratio of the samples and standards except for that of sample FSB 104D, where the ratio of the blank was $47 \%$ of the measured ${ }^{129} \mathrm{I}^{127} \mathrm{I}$ ratio for $\mathrm{I}^{-}$.

\subsection{Groundwater Sampling and Measurement of Geochemical Properties}

Groundwater samples, obtained from 8 wells of the SRS F-Area (Fig. 1), were prepared as outlined in Fig. S1 and then measured by AMS.

Details of groundwater sampling and analysis of geochemical parameters $(\mathrm{pH}, \mathrm{Eh}$, and dissolved organic carbon (DOC) concentrations) are described in Otosaka et al. (2011). In short, the wells were initially purged to remove stagnant water and then the groundwater samples were collected at low flow rate $(0.5 \mathrm{~L} / \mathrm{min})$ using a variable speed submersible pump (Grundfos Redi-flo 2, Olathe, KS) or a battery-operated peristaltic pump. The purged water was passed through an on-line YSI flow through cell (6820 and 6920, Yellow Springs, OH) in which temperature, $\mathrm{pH}$, oxidation-reduction potential (ORP or Eh), dissolved oxygen, and 
electrical conductivity were monitored. Once the $\mathrm{pH}$ and conductivity readings were stable, the well water was sampled ( 2 well volumes). Surface water from the Fourmile Branch was collected using a bottle attached to a pole to obtain a sample from the center of the creek (5-m wide), about $0.3 \mathrm{~m}$ below the surface. All surface water and groundwater samples were pumped in the field through a $0.45 \mu \mathrm{m}$ cartridge filter into an amber container and stored in a refrigerator until analysis.

\section{Results and discussion}

\subsection{Comparison of AMS and GC-MS ${ }^{129}$ I measurements}

The concentrations of ${ }^{129} \mathrm{I}^{-},{ }^{129} \mathrm{I}-\mathrm{TII}$ and ${ }^{129} \mathrm{I}-\mathrm{TI}$ in four groundwater samples were measured using AMS and GC-MS (Fig. 2). The ${ }^{129} \mathrm{I}$ species of ${ }^{129} \mathrm{I}^{-},{ }^{129} \mathrm{IO}_{3}{ }^{-},{ }^{129} \mathrm{I}-\mathrm{IO}$, wherein ${ }^{129} \mathrm{IO}_{3}{ }^{-}$and ${ }^{129} \mathrm{I}-\mathrm{IO}$ calculated from the measured concentrations are presented in Table 1. When taking into account that the uncertainties in the measurements for AMS and GC-MS were determined differently, there is general agreement between the two methods. The uncertainties of AMS measurement represent the 2-sigma counting statistics of the sample including the uncertainty of the standard (counting statistics and theoretical value), as well as uncertainty propagation, while those of GC-MS represent the standard deviation calculated from duplicate or triplicate measurements (Table 1, Fig. 2). Although no duplicate AMS samples were carried throughout the preparation protocol, triplicate ${ }^{129} \mathrm{I} /{ }^{127} \mathrm{I}$ measurements by AMS in the range analyzed generally produced $\sim 7 \%$ of reproducibility for the entire sequence of sample treatment.

Results of ${ }^{129} \mathrm{I}$ measurements using AMS and GC-MS showed agreement within 2-sigma statistics for groundwater samples with activity concentrations greater than $0.5 \mathrm{~Bq} / \mathrm{L}$ (on the AMS scale). Apparently, below 0.5 Bq/L ${ }^{129} \mathrm{I}$, the GC-MS measurements indicated a slightly higher activity concentrations than the AMS measurements (Fig. 2) and below this concentration the GC-MS no longer was within the linear detection range. Therefore, the AMS values supersede the GC-MS values below $0.5 \mathrm{~Bq} / \mathrm{L}$. The data actually used for further 
evaluation and interpretation is shown in Table 2 (excluding the superseded GC-MS values below $0.5 \mathrm{~Bq} / \mathrm{L})$.

\subsection{Influence of groundwater chemistry on ${ }^{129}$ I speciation at the SRS F-Area}

To put the ${ }^{129} \mathrm{I}$ speciation and concentration data into perspective, ancillary groundwater parameters were also measured ( $\mathrm{pH},{ }^{3} \mathrm{H}$, Eh, and DOC concentrations; Table 2). Some of this groundwater data from near the seepage basins was previously reported by Otosaka et al. (2011); these are indicated in Table 2.

Relationships between the concentrations of ${ }^{129} \mathrm{I}$ (determined by either method), $\mathrm{pH},{ }^{127} \mathrm{I},{ }^{3} \mathrm{H}$ and DOC (Fig. S2a-d, supporting information (SI)) indicate that groundwater impacted by strongly acidic waste (introduced to the seepage basins in a pH $1-3$ waste stream containing high levels of $\mathrm{HNO}_{3}$ had greater ${ }^{129} \mathrm{I}$ concentrations (Fig. S2a), confirming that ${ }^{129} \mathrm{I}$ and the acidity had similar sources (Table 2). Interestingly, ${ }^{129} \mathrm{I} /{ }^{127} \mathrm{I}$ isotopic ratios in the groundwater samples with the greatest ${ }^{129}$ I concentrations $\left({ }^{129} \mathrm{I}\right.$ concentrations ranging from 1.72 to 10.55 Bq/L in wells FSB-95DR, FSB-117D, FSB-126D, FPZ-6A and FSB-79), were within the same order of magnitude, with FSB-79 presumably showing some mixing (Table2, Fig. S2b), indicating that stable I may have been simultaneously disposed with other waste (perhaps as a trace constituent of nitrate or sodium that was introduced in molar concentrations to the seepage basin over the 33 years of operation). Furthermore, ${ }^{129} \mathrm{I}$ and ${ }^{3} \mathrm{H}$ concentrations showed a correlation in the low contamination region (Fig. S2c), suggesting a common source. No significant relationship was observed between ${ }^{129}$ I and DOC (Fig. S2d), suggesting that their sources were different (Otosaka et al., 2011).

${ }^{129} \mathrm{I}$ and ${ }^{127} \mathrm{I}$ concentrations correlate well for $\mathrm{I}^{-}$, and all three I species when only contaminated samples are considered (Fig. 3; using the 5 most contaminated samples (Table $\mathrm{S} 1)$, the linear regression for total iodine was ${ }^{129} \mathrm{I}=28.1\left({ }^{127} \mathrm{I}\right)+60.5$, with $\left.\mathrm{r}=0.951, \mathrm{p} \leq 0.01\right)$. Further, the ${ }^{129} \mathrm{I}^{-} /{ }^{127} \mathrm{I}^{-}$and ${ }^{129} \mathrm{IO}_{3}{ }^{-} /{ }^{127} \mathrm{IO}_{3}{ }^{-}$isotopic ratios of these 5 more contaminated groundwater samples were also very closely correlated to $\mathrm{pH}(\mathrm{r}=0.838$ and -0.956 , respectively; $\mathrm{p} \leq 0.01$ ) (Table $\mathrm{S} 1$ ). As $\mathrm{pH}$ increased the percentage of ${ }^{129} \mathrm{I}^{-}$concentrations increased with respect to ${ }^{127} \mathrm{I}^{-}$concentrations; conversely, as the $\mathrm{pH}$ increased the ${ }^{129} \mathrm{IO}_{3}{ }^{-}$ 
decreased with respect to ${ }^{127} \mathrm{IO}_{3}{ }^{-}$concentrations (Table S1).

Effective transfer of ${ }^{129} \mathrm{IO}_{3}{ }^{-}$from groundwater to aquifer sediments is a probable cause explaining the generally lower ${ }^{129} \mathrm{I} /{ }^{127} \mathrm{I}$ ratios of $\mathrm{IO}_{3}{ }^{-}$in the dissolved phase compared to ${ }^{129} \mathrm{I} /{ }^{127} \mathrm{I}$ ratios of $\mathrm{I}^{-}$. Since there is a larger pool of natural stable ${ }^{127} \mathrm{I}$ in the sediments relative to ${ }^{129} \mathrm{I}$, the release of both isotopes with more naturally available ${ }^{127}$ I may effectively lower the isotopic ratios. However, the cause for this is not known, but may be attributed to the multiple sources (natural and anthropogenic) and longer residency of stable ${ }^{127}$ I versus those of ${ }^{129}$ I. Another confounding factor is likely that there appears to have been more than one source of organic carbon in the plume, natural and anthropogenic (Table 2), and organic carbon has been shown to have a significant impact on I tendency to partition to soils (Xu et al., 2011a, b). Again, it is not known why these factors would potentially influence $\mathrm{IO}_{3}{ }^{-}$- and organo- ${ }^{129} \mathrm{I} /{ }^{127} \mathrm{I}$ ratios, but not the $\mathrm{I}^{-}{ }^{129} \mathrm{I} /{ }^{127} \mathrm{I}$ ratios.

In this set of samples, the percentage of OI ranges from 0 to $82.4 \%$ with an average of $36.8 \%$ for both isotopes. This is similar to the average OI concentrations as $38 \%$ with a range of 18 to $58 \%$, described by Otosaka et al. (2011). Organo-I in the most contaminated groundwater samples had a higher ${ }^{129} \mathrm{I} /{ }^{127} \mathrm{I}$ ratio $(0.048 \pm 0.035 ; \mathrm{n}=5)$ than in the groundwater less impacted by the plume $(0.006 \pm 0.007 ; \mathrm{n}=4)$. It is known that the production and decomposition of OI is controlled by multiple factors such as the properties of soil organic matter, microbial processes, and other geochemical parameters (Xu et al., 2011a, b; Li et al., 2012). Therefore, the difference in the OI- ${ }^{129} \mathrm{I} /{ }^{127} \mathrm{I}$ ratios between the plume and the less contaminated aquifer waters appears to be a more complex process beyond the scope of this study. In the less contaminated regions of the aquifer, a significant relationship between ${ }^{129} \mathrm{I}$ and ${ }^{127}$ I concentrations was not observed (Fig. 3c), suggesting that the isotopes have different resident times and thus, different sources.

\subsection{Comparison to pristine environments in the USA}

It is important to note that outside the plume region, ${ }^{129} \mathrm{I}$ concentrations are still greatly elevated compared to ambient concentrations in US rivers, and even compared to the Savannah River, bordering the SRS, which was contaminated with ${ }^{129} \mathrm{I}$ in the past (Fig. 4) 
(Kantelo et al. 1990). The F-Area plume flows into Fourmile Branch, which in turn flows another $7 \mathrm{~km}$ to the Savannah River. In the past, ${ }^{129} \mathrm{I}$ was accidently and purposely released by air emissions at F-Area (Kantelo et al. 1990). It can be assumed to be present in most places on the SRS near the former reprocessing facilities (F- and H-Areas) due to its tendency to volatilize in acidic environments and in the presence of simple organics (via methylation). Volatilized or particulate ${ }^{129}$ I entered the environment through air emissions, and after that, could have readily concentrated in the surface environment, especially where organic carbon is concentrated, i.e., wetlands. Thus, it is not surprising that the farfield locations in the SRS F-area have elevated ${ }^{129} \mathrm{I}$ concentrations relative to ambient concentrations further from the SRS site. Interestingly, Fig. 4 shows that our recent measurement of ${ }^{129}$ I-TI in the Savannah River (sampled in 2010) was 2 orders of magnitude higher than in the sample taken in 1996, suggesting that since 1996, more ${ }^{129}$ I has been released into the environment through continuous biogeochemical cycling of I species (presumably, originally absorbed by organic carbon in the area during the operating years of nuclear fuel reprocessing at the SRS facility) through phases of volatile methylated or particulate species to phases reabsorbed on organic carbon again.

\section{Conclusions and summary}

A pH-controlled, solvent extraction method for ${ }^{129} \mathrm{I}^{127} \mathrm{I}$ measurement for $\mathrm{I}^{-}, \mathrm{IO}_{3}{ }^{-}$ and OI using AMS extended the range of a recently developed GC-MS method (Zhang et al. 2010) for ${ }^{129} \mathrm{I}$ and ${ }^{127} \mathrm{I}$ speciation measurements at contaminated levels. Measured concentrations and associated uncertainties of the two methods were in good agreement in samples containing > $0.5 \mathrm{~Bq} / \mathrm{L}{ }^{129} \mathrm{I}$. TI, and individual I species data from groundwater samples determined by AMS and GC-MS measurements agreed within 2-sigma in the ${ }^{129} \mathrm{I}$ concentration range of $>0.5 \mathrm{~Bq} / \mathrm{L}$. Uncertainties in the I speciation separation and combustion procedures used in this study can be decreased by using ${ }^{125} \mathrm{I}$ as a yield tracer and are $10 \%$ or less propagated uncertainty for ${ }^{129} \mathrm{I}^{-}$and ${ }^{129} \mathrm{IO}_{3}{ }^{-}$species determination, and $30 \%$ or less between the replicates of the combustion process for organo- ${ }^{129} \mathrm{I}$. In the groundwater 
system at SRS F-Area, the anthropogenic acidic ${ }^{129}$ I plume has migrated down gradient, until the $\mathrm{pH}$ rises sufficiently to promote I desorption. Since ${ }^{127} \mathrm{I}$ has a relatively higher abundance than ${ }^{129} \mathrm{I}$, it is suggested that for this reason the ${ }^{129} \mathrm{I} /{ }^{127} \mathrm{I}$ ratios decrease in the higher $\mathrm{pH}$, less ${ }^{129}$ I contaminated aquifer. Lower ${ }^{129}$ I activity samples outside the ${ }^{129}$ I plume area are still orders of magnitude higher than ambient ${ }^{129}$ I concentrations elsewhere in the USA. This is likely due to past atmospheric releases of volatile ${ }^{129}$ I species at SRS as part of operations before 1990 .

This study underscores the importance of understanding the biogeochemical behavior of a contaminant across the range of plume gradient concentrations. In such systems, the speciation may be more reflective of the source and not as greatly influenced by the presence of soil and SOM. Regarding our hypothesis that I species would remain the same across the gradient from the highest level of contamination to the lowest level, we determined that the relationship of ${ }^{127} \mathrm{I}^{-}$vs. ${ }^{129} \mathrm{I}^{-}$was correlative while those for $\mathrm{IO}_{3}{ }^{-}$and OI were valid only within the higher plume concentrations. Further, the ${ }^{129} \mathrm{I}^{-} /{ }^{127} \mathrm{I}^{-}$and ${ }^{129} \mathrm{IO}_{3}{ }^{-} /{ }^{127} \mathrm{IO}_{3}{ }^{-}$isotopic ratios of these 5 more contaminated groundwater samples were also very closely correlated to $\mathrm{pH}$. As $\mathrm{pH}$ increased the percentage of ${ }^{129} \mathrm{I}^{-}$concentrations increased with respect to ${ }^{127} \mathrm{I}^{-}$ concentrations; conversely, as the $\mathrm{pH}$ increased the ${ }^{129} \mathrm{IO}_{3}{ }^{-}$decreased with respect to ${ }^{127} \mathrm{IO}_{3}{ }^{-}$ concentrations. By studying ${ }^{129}$ I concentrations less impacted by the contaminant plume, it was possible to discern that in fact there was a second source term (atmospheric emission prior to 1990), albeit a significantly less important one with respect to its contribution to the F-Area plume. This conclusion was supported by AMS isotopic ratio and concentration data, as well as ancillary information about the plume, $\mathrm{pH}$, and ${ }^{3} \mathrm{H}$ concentrations. While the ${ }^{129} \mathrm{I}$ concentrations in the area contaminated by atmospheric releases are 1 to 2 orders of magnitude below plume sourced by the seepage basin, they provide added understanding of ${ }^{129}$ I at the study site that may be of value for risk modeling of episodic events.

\section{Acknowledgements}

We would like to thank E. Nottoli for her valuable assistance during the AMS 
measurements that were performed at the French AMS national facility ASTER (CEREGE, Aix-en-Provence) which is supported by the INSU/CNRS, the French Ministry of Research and Higher Education, IRD and CEA. This work was partially funded by a German-French exchange program (DAAD and ÉGIDE), and the U.S. Department of Energy's (DOE) Subsurface Biogeochemical Research (SBR) Program within the Office of Science (ER65222-1038426-0017532). 


\section{References}

Aldahan A, Kekli A, Possnert G. Distribution and sources of ${ }^{129} \mathrm{I}$ in rivers of the Baltic region. J Environ Radioact 2006; 88: 49-73.

Arnold M, Aumaître G, Bourlès DL, Keddadouche K, Braucher R, Finkel RC, Nottoli E, Benedetti L, Merchel S. The French accelerator mass spectrometry facility ASTER after 4 years: Status and recent developments on ${ }^{36} \mathrm{Cl}$ and ${ }^{129} \mathrm{I}$. Nucl Instr Meth Phys Re. B 2013; 294: 24-28, doi:10.1016/j.nimb.2013.01.049.

Arnold M, Merchel S, Bourlès DL, Braucher R, Benedetti L, Finkel RC, Aumaître G, Gottdang A, Klein M. The French accelerator mass spectrometry facility ASTER: Improved performance and developments. Nucl Instr Meth Phys Res B 2010; 268: 1954-1959.

Beasley TM, Cooper LW, Grebmeier JM, Kilius LR, Synal HA. ${ }^{36} \mathrm{Cl}$ and ${ }^{129} \mathrm{I}$ in the Yenisei, Kolyma, and Mackenzie Rivers. Environ Sci Tech 1997; 31: 1834-1836.

Cochran JK, Moran SB, Fisher NS, Beasley TM, Kelley JM. Sources and transport of anthropogenic radionuclides in the Ob River system, Siberia. Earth Planet Sci Lett 2000; 179: $125-137$.

Dai M.; Kelley, J.M.; Buesseler, K.O. Sources and migration of plutonium in groundwater at the Savannah River Site. Environ. Sci. Technol. 2002; 36, 3690-3698.

Emerson HP, Xu C, Ho Y-F, Zhang S, Schwehr KA, Lilley M, Kaplan DI, Santschi PH, Powell BA. Geochemical controls of iodine uptake and transport in Savannah River Site subsurface sediments. Applied Geochem. 2014; (accepted).

Emery JF, Reynolds SA, Wyatt EI, Gleason GI. Half-lives of radionuclides -IV. Nuclear Science and Eng 1972; 48: 319-323.

Fabryka-Martin J, Bentley H, Elmore D, Airey PL. Natural iodine-129 as an environmental tracer. Geochim Cosmochim Acta 1985; 49: 337-347.

Hou X, Hansen V, Aldahan A, Possnert G, Christian Lind O, Lujaniene G. A review on speciation of iodine-129 in the environmental and biological samples. Analyt Chim Acta 2008; 632: 181-196.

Hou X, Hou Y. Analysis of ${ }^{129} \mathrm{I}$ and its application as environmental tracer. J Analyt Sci Tech 2012; 3: 135-153.

Hou X, Povinec PP, Zhang L, Shi K, Biddulph D, Chang C-C, Fan Y, Golser R, Hou Y, Jeskovsky M, Jull AJT, Liu Q, Luo M, Steier P, Zhou Q. Iodine-129 in seawater offshore 
Fukushima: distribution, inorganic speciation, sources, and budget. Environ Sci Tech 2013; 47: 3091-3098.

Hou X, Aldahan A, Possnert G, Lujaniene G, Lehto J, Skipperud L, Lind OC, Salbu B. Speciation analysis of radionuclides in the environment. NSK-B Speciation project report 205, Nordic nuclear safety research, ISBN 978-87-7893-274-7, 2009.

Kantelo MV, Bauer LR, Marter WL, Murphy CE, Jr. 1990. Radioiodine in the Savannah River Site Environment. WSRC-RP-90-424-2. Westinghouse Savannah River Company, Aiken, SC.

Kaplan DI, Denham ME, Zhang S, Yeager C, Xu C, Schwehr KA, Li HP, Ho YF, Wellman D, Santschi PH. Radioiodine biogeochemistry and prevalence in groundwater. Environ Sci Technol Critical Reviews 2013; (in press). DOI:10.1080/10643389.2013.828273.

Kaplan DI, Roberts KA, Schwehr KA, Lilley MS, Brinkmeyer R, Denham ME, DiPrete D, Li H-P, Powell BA, Xu C, Yeager CM, Zhang SJ, Santschi PH. Evaluation of a Radioiodine Plume Increasing in Concentration at the Savannah River Site. Environ Sci Technol 2011; 45: 489-495.

Lehto J, Räty T, Hou X, Paatero J, Aldahan A, Possnert G, Flinkman J, Kankaanpää H. Speciation of ${ }^{129} \mathrm{I}$ in sea, lake and rain waters. Sci Total Environ 2012; 419: 61-67.

Li H-P, Yeager CM, Brinkmeyer R, Zhang S, Ho Y-F, Xu C, Jones WL, Schwehr KA, Otosaka S, Roberts KA, Kaplan DI, Santschi PH. Bacterial production of organic acids enhances $\mathrm{H}_{2} \mathrm{O}_{2}$-dependent iodine oxidation. Environ Sci Technol 2012; 46: 4837-4844.

Moran JE, Oktay S, Santschi PH, Schink DR. Atmospheric dispersal of ${ }^{129}$ Iodine from European nuclear fuel reprocessing facilities. Environ Sci Technol 1999; 33(15): 2536-2542.

Moran JE, Oktay SD, Santschi PH. Sources of iodine and iodine-129 in rivers. Water Res Res 2002; 38: 24-1-21-10.

Muramatsu Y, Takadaa Y, Matsuzaki H, Yoshida S. AMS analysis of ${ }^{129}$ I in Japanese soil samples collected from background areas far from nuclear facilities. Quaternary Geochron 2008; 3: 291-297.

Otosaka S, Schwehr KA, Kaplan DI, Roberts KA, Zhang S, Xu C, Li H-P, Ho Y-F, Brinkmeyer R, Yeager CM, Santschi PH. Transformation and transport processes of ${ }^{127} \mathrm{I}$ and ${ }^{129} \mathrm{I}$ species in an acidic groundwater plume at the Savannah River Site. Sci Total Environ 2011; 409: 3857-3865. 
Santschi PH, Schink DR, Corapcioglu O, Oktay-Marshall S, Sharma P, Fehn U. Evidence for elevated levels of Iodine-129 in the deep Western Boundary Current in the Middle Atlantic Bight. Deep-Sea Res, 1996; 43: 259-265.

Santschi PH, Schwehr KA. ${ }^{129} \mathrm{I} /{ }^{127} \mathrm{I}$ as a new environmental tracer or geochronometer for biogeochemical or hydrodynamic processes in the hydrosphere and geosphere: the central role of organo-iodine. Sci Total Environ 2004; 321: 257-271.

Savannah River Nuclear Solutions, LLC, Savannah River Site Groundwater Strategy and Implementation Plan, WSRC-RP-2006-4074. Savannah River Nuclear Solutions, LLC. Aiken, SC, 2008.

Schink DR, Santschi PH, Corapcioglu O, Sharma P, Fehn U. ${ }^{129}$ I in Gulf of Mexico waters. Earth Planet Sci Lett 1995; 135: 131-138.

Schwehr, K.A.; Santschi, P.H.; Moran, J.E.; Elmore, D. Near-conservative behavior of ${ }^{129}$ I in the Orange county aquifer system, California. Appl Geochem 2005; 20: 1461-1472.

Schwehr, K.A.; Santschi, P.H.; Elmore, D. The dissolved organic iodine species of the isotopic ratio of ${ }^{129} \mathrm{I} /{ }^{127} \mathrm{I}$ : A novel tool for tracing terrestrial organic carbon in the estuarine surface waters of Galveston Bay, Texas. Limnol. Oceanogr. Methods 2005; 3: 326-227.

Schwehr KA, Santschi PH, Kaplan DI, Yeager CM, Brinkmeyer R. Organo-iodine formation in soils and aquifer sediments at ambient concentrations. Environ Sci Technol 2009; 43: 7258-7264.

Snyder G, Fehn U. Global distribution of ${ }^{129}$ I in rivers and lakes: implications for iodine cycling in surface reservoirs. Nucl Instrum and Methods in Physics Res B 2004; 223-224: 579-586.

Strachnov V, LaRosa J, Dekner R, Zeisler R, Fajgelj A. Report on the Intercomparison run IAEA-375: Radionuclides in Soil. IAEA/AL/075, IAEA, Vienna, Austria, 1996.

Suzuki T, Banba S, Kitamura T, Kabuto S, Isogai K, Amano H. Determination of ${ }^{129}$ I in environmental samples by AMS and NAA using an anion exchange disk. Nucl Inst Methods Phys Res B 2009; 259: 370-373.

Szidat S, Schmidt A, Handl J, Jakob D, Michel R, Synal HA, Schnabel C, Suter M, Lopez-Gutierrez JM. RNAA and AMS of iodine-129 in environmental materials comparison of analytical methods and quality assurance. Kerntechnik 2000; 65: 160-167. 
Xu C, Zhang S, Ho Y-F, Miller EJ, Roberts KA, Li H-P, Schwehr KA, Otosaka S, Kaplan DI, Brinkmeyer R, Yeager CM, Santschi PH. Is soil natural organic matter a sink or source for radioiodine $\left({ }^{129} \mathrm{I}\right)$ at the Savannah River Site? Geochim Cosmochim Acta 2011; 75 : $5716-5735$.

Xu C, Miller EJ, Zhang S, Li H-P, Ho Y-F, Schwehr KA, Kaplan DI, Roberts KA, Otosaka S, Brinkmeyer R, Yeager CM, Santschi PH. Sequestration and re-mobilization of radioiodine $\left({ }^{129} \mathrm{I}\right)$ by soil organic matter and possible consequences of the remedial action at Savannah River Site. Environ Sci Technol 2011; 45: 9975-9983.

Zhang S, Schwehr KA, Ho Y-F, Xu C, Roberts KA, Kaplan DI, Brinkmeyer R, Yeager CM, Santschi PH. A novel approach for the simultaneous determination of iodide, iodate and organo-iodide for ${ }^{127} \mathrm{I}$ and ${ }^{129} \mathrm{I}$ in environmental samples using gas chromatography-mass spectrometry. Environ Sci Technol 2010; 44: 9042-9048.

Zhang S, Du J, Xu C, Schwehr KA, Ho Y-F, Li H-P, Roberts KA, Kaplan DI, Brinkmeyer R, Yeager CM, Chang H-S, Santschi PH. Concentration dependent mobility, retardation and speciation of iodine in surface sediment from the Savannah River Site. Environ Sci Technol 2011; 45: 5543-5549. 
Table 1. Comparison of ${ }^{129} \mathrm{I}^{-},{ }^{129} \mathrm{IO}_{3}{ }^{-}$, and organo- ${ }^{129} \mathrm{I}$ concentration in seven groundwater samples measured by AMS and GC-MS.

\begin{tabular}{|c|c|c|c|c|c|c|}
\hline \multirow[t]{3}{*}{ 'Station } & \multicolumn{6}{|l|}{ AMS } \\
\hline & \multicolumn{6}{|c|}{${ }^{129} \mathrm{I}(\mathrm{Bq} / \mathrm{L})$} \\
\hline & $b^{-}$ & $c_{ \pm}$ & $\mathrm{IO}_{3}{ }^{-}$ & \pm & OI & \pm \\
\hline FSB $126 \mathrm{D}$ & 1.32 & 0.09 & 0.17 & 0.09 & 0.46 & 0.59 \\
\hline FSB 79 & 1.51 & 0.11 & 0.09 & 0.11 & 0.12 & 0.52 \\
\hline FSB $104 \mathrm{D}$ & 0.01 & 0.00 & 0.13 & 0.00 & end & \\
\hline FSB $138 \mathrm{D}$ & 0.11 & 0.01 & 0.05 & 0.01 & 0.18 & 0.10 \\
\hline FPZ $3 \mathrm{~A}$ & 0.05 & 0.004 & 0.02 & 0.004 & 0.06 & 0.04 \\
\hline FSB $109 D$ & 0.03 & 0.002 & 0.000 & 0.002 & 0.01 & 0.01 \\
\hline $\begin{array}{l}\text { Fourmile } \\
\text { Branch }\end{array}$ & 0.29 & 0.02 & 0.03 & 0.02 & 0.00 & 0.09 \\
\hline
\end{tabular}

\begin{tabular}{cccccc}
\hline${ }^{d} \mathrm{GCMS}$ & & & & & \\
\hline${ }^{129} \mathrm{I}(\mathrm{Bq} / \mathrm{L})$ & & & & & \\
$\Gamma^{-}$ & \pm & $\mathrm{IO}_{3}{ }^{-}$ & \pm & $\mathrm{OI}$ & \pm \\
\hline 1.15 & 0.18 & 0.91 & 0.34 & 0.00 & 1.00 \\
1.29 & 0.28 & 0.00 & 0.29 & 0.59 & 0.30 \\
${ }_{\mathrm{BDL}}$ & & 0.73 & 0.18 & 0.27 & 0.64 \\
$\mathrm{BDL}$ & & 0.34 & 0.10 & 0.81 & 0.36 \\
$\mathrm{BDL}$ & & $\mathrm{BDL}$ & & $\mathrm{BDL}$ & \\
$\mathrm{BDL}$ & & $\mathrm{BDL}$ & & $\mathrm{BDL}$ & \\
$\mathrm{BDL}$ & & $\mathrm{BDL}$ & & $\mathrm{BDL}$
\end{tabular}

${ }^{\text {a }}$ Sample location is identified in Fig. 1.

${ }^{\mathrm{b}} \mathrm{I}^{-}=$iodide $; \mathrm{IO}_{3}{ }^{-}=\mathrm{TII}=$ total inorganic iodine $-[$ iodide $] ; \mathrm{OI}=$ organo- $\mathrm{I}=\mathrm{TI}-\mathrm{TII}$

${ }^{\mathrm{c}}$ The uncertainties of AMS measurement include the 2-sigma counting statistics $(<10 \%)$ and theoretical value from chemical processing, while those of GC-MS include the standard deviation calculated from duplicate or triplicate measurements. Both include propagation uncertainties for the I speciation method.

${ }^{\mathrm{d}}$ GC-MS data taken from Otosaka et al. (2011).

${ }^{\mathrm{e}} \mathrm{nd}=$ not determined

${ }^{\mathrm{f}} \mathrm{BDL}=$ below detection limit 
Table 2. Isotopic and speciation data for I, as well as field collected parameters ( $\mathrm{pH}$ and Eh), ancillary data including ${ }^{3} \mathrm{H}$ and dissolved organic carbon (DOC) concentrations. Samples from FSB 95DR, FSB 117D, FSB 126D, and FPZ 6A have high 129I $\mathrm{Bq} / \mathrm{L}$ activities and are within the plume. The sample from FSB 79 is within a mixing zone between the higher concentrations in the plume and the farfield sample sites, i.e., FSB 104D, FSB 138D, FPZ 3A, FSB 109D, and the Fourmile Branch.

\begin{tabular}{|c|c|c|c|c|c|c|c|c|c|c|c|c|c|c|c|c|c|c|c|c|c|}
\hline \multirow[b]{3}{*}{ Samples: } & \multirow{3}{*}{$\begin{array}{l}\text { Sampling } \\
\text { date }\end{array}$} & \multirow{2}{*}{\multicolumn{2}{|c|}{${ }^{3} \mathrm{H}^{\mathrm{e}}$}} & \multirow[t]{2}{*}{$\mathrm{Eh}^{\mathrm{c}}$} & \multirow[t]{2}{*}{$\mathrm{DOC}^{\mathrm{C}}$} & \multirow{2}{*}{\multicolumn{2}{|c|}{$127 \mathrm{I}^{\mathrm{c}}$}} & \multirow{2}{*}{\multicolumn{2}{|c|}{$\mathrm{IO}_{3}{ }^{\circ}$}} & \multirow{2}{*}{\multicolumn{2}{|c|}{ OI }} & \multirow{2}{*}{\multicolumn{6}{|c|}{129}} & \multicolumn{4}{|c|}{${ }^{129} \mathrm{I} /{ }^{127} \mathrm{I}$ atom ratio } \\
\hline & & & & & & & & & & & & & & & & & & $i^{\circ}$ & $\mathrm{IO}_{3}{ }^{\circ}$ & Ol & $\mathrm{TI}$ \\
\hline & & $\mathrm{pH}^{\mathrm{c}}$ & $\mathrm{kBq} / \mathrm{L}$ & $\mathrm{mV}$ & $\begin{array}{c}\text { umol } \\
\mathrm{L}^{-1}\end{array}$ & $\mathrm{nmol} / \mathrm{L}$ & \pm & $\mathrm{nmol} / \mathrm{L}$ & \pm & $\mathrm{nmol} / \mathrm{L}$ & \pm & $\mathrm{Bq} / \mathrm{L}$ & \pm & $\mathrm{Bq} / \mathrm{L}$ & \pm & $\mathrm{Bq} / \mathrm{L}$ & \pm & & & & \\
\hline${ }^{\mathrm{b}} \mathrm{FSB}$ 95DR & $8 / 3 / 2009$ & 3.2 & 23.3 & 654 & 60.5 & 189.9 & 13.2 & 70.2 & 24.6 & 110.2 & 28.3 & 5.81 & 0.68 & 1.52 & 0.72 & 3.23 & 0.82 & 0.04 & 0.03 & 0.043 & 0.120 \\
\hline${ }^{\mathrm{b}} \mathrm{FSB}$ 117D & $7 / 12 / 2010$ & 3.6 & 27.1 & 494 & 8.3 & 75.6 & 4.3 & 60.6 & 16.0 & 73.6 & 17.9 & 1.29 & 0.45 & 0.97 & 0.46 & 2.52 & 0.74 & 0.03 & 0.02 & 0.050 & 0.099 \\
\hline FSB 126D & $8 / 3 / 2010$ & 3.4 & 70.7 & 491 & 29.9 & 80.6 & 4.5 & 12.0 & 10.4 & 16.8 & 11.0 & 1.32 & 0.09 & 0.17 & 0.03 & 0.46 & 0.31 & 0.02 & 0.02 & 0.041 & 0.086 \\
\hline${ }^{b}$ FPZ 6A & $7 / 21 / 2010$ & 3.8 & 95.1 & 391 & 13.8 & 72.9 & 4.2 & 34.9 & 13.6 & 32.4 & 14.8 & 1.41 & 0.16 & 1.09 & 0.30 & 2.23 & 0.34 & 0.03 & 0.05 & 0.101 & 0.176 \\
\hline FSB 79 & $7 / 9 / 2010$ & 5.2 & 25.3 & 428 & 16.2 & 56.1 & 1.9 & 27.8 & 5.1 & 56.1 & 23.0 & 1.51 & 0.11 & 0.08 & 0.03 & 0.12 & 0.28 & 0.04 & 0.004 & 0.003 & 0.047 \\
\hline FSB 104D & $7 / 12 / 2010$ & 6.7 & 0.1 & 402 & 22.6 & 13.6 & 1.6 & 75.0 & 4.3 & 48.8 & 6.5 & 0.01 & 0.00 & 0.13 & 0.004 & nd & & 0.001 & 0.003 & nd & 0.003 \\
\hline FSB $138 \mathrm{D}$ & $8 / 24 / 2010$ & 4.2 & 8.5 & 384 & 15.5 & 12.9 & 0.2 & 35.1 & 3.0 & 19.9 & 5.0 & 0.11 & 0.011 & 0.05 & 0.002 & 0.18 & 0.05 & 0.01 & 0.002 & 0.013 & 0.028 \\
\hline FPZ $3 \mathrm{~A}$ & $7 / 21 / 2010$ & 4.1 & 5.3 & 487 & 33.4 & 5.1 & 2.3 & 7.5 & 2.5 & 24.1 & 2.7 & 0.05 & 0.004 & 0.02 & 0.001 & 0.06 & 0.020 & 0.02 & 0.003 & 0.003 & 0.022 \\
\hline FSB 109D & $7 / 9 / 2010$ & 5.5 & 2.0 & 381 & 35.6 & 3.0 & 3.0 & 4.6 & 3.2 & 35.5 & 3.0 & 0.03 & 0.002 & 0.00 & 0.001 & 0.01 & 0.001 & 0.01 & 0.000 & 0.000 & 0.014 \\
\hline $\begin{array}{l}\text { Fourmile } \\
\text { Branch }\end{array}$ & $7 / 13 / 2010$ & 6.7 & 0.0 & 366 & 358.0 & 39.4 & 3.5 & 18.6 & 4.6 & 82.6 & 7.9 & 0.29 & 0.021 & 0.02 & 0.021 & 0.02 & 0.050 & 0.01 & 0.002 & 0.000 & 0.013 \\
\hline
\end{tabular}

${ }^{\text {a }}$ Sample locations identified in Fig. 1.

${ }^{\mathrm{b}}$ indicates samples run by GCMS, Otosaka et al. (2011); the others were determined by AMS, this study.

${ }^{c}$ Otosaka et al. (2011) wherein ${ }^{127}$ I and ${ }^{129}$ I were measured using the GC-MS method of Zhang et al. 2010. 


\section{Fig. captions}

Fig.1. Map of Savannah River Site's (SRS) F-Area, locating sampling sites. The approximate boundary of the ${ }^{129} \mathrm{I}$ plume, as defined by the $1 \mathrm{pCi} / \mathrm{L}$ regulatory limit, is shown as a dashed line. Groundwater flow is generally to the south towards Fourmile Branch. The Fourmile Branch sample was collected 130 m downstream, to the east (left), off the map. Fourmile Branch flows into the Savannah River, which borders the western side of South Carolina (inset) and flows to the Atlantic Ocean.

Fig. 2. AMS and GC-MS ${ }^{129} \mathrm{I}$ concentrations measured directly (the other chemical species shown in Table 1 were calculated by difference, see 2 . Materials and methods).

Fig. 3. AMS (triangles) and GC-MS (circles) ${ }^{129} \mathrm{I}$ and ${ }^{127} \mathrm{I}$ concentrations for (a) $\mathrm{I}^{-}$, (b) $\mathrm{IO}_{3}{ }^{-}$, and (c) OI. The contaminated acidic plume symbols are dark and the less contaminated groundwater symbols are open. Since the detection limit for GC-MS was set at $>1 \mathrm{~Bq} / \mathrm{L}$, there are no GC-MS data included here for the less contaminated groundwater.

Fig. 4. Comparison of ${ }^{129}$ I-TI concentrations: circles are data in this study and (Otosaka et al., 2011), black circles are in the plume, grey circles are on the periphery of the plume, white circle is outside the plume; and squares are for select rivers and the natural pre-atomic era background concentration (Moran et al., 2002). Sample locations outside of the parenthesis are keyed into the map (Figure 1) and sample dates are noted in parentheses. 


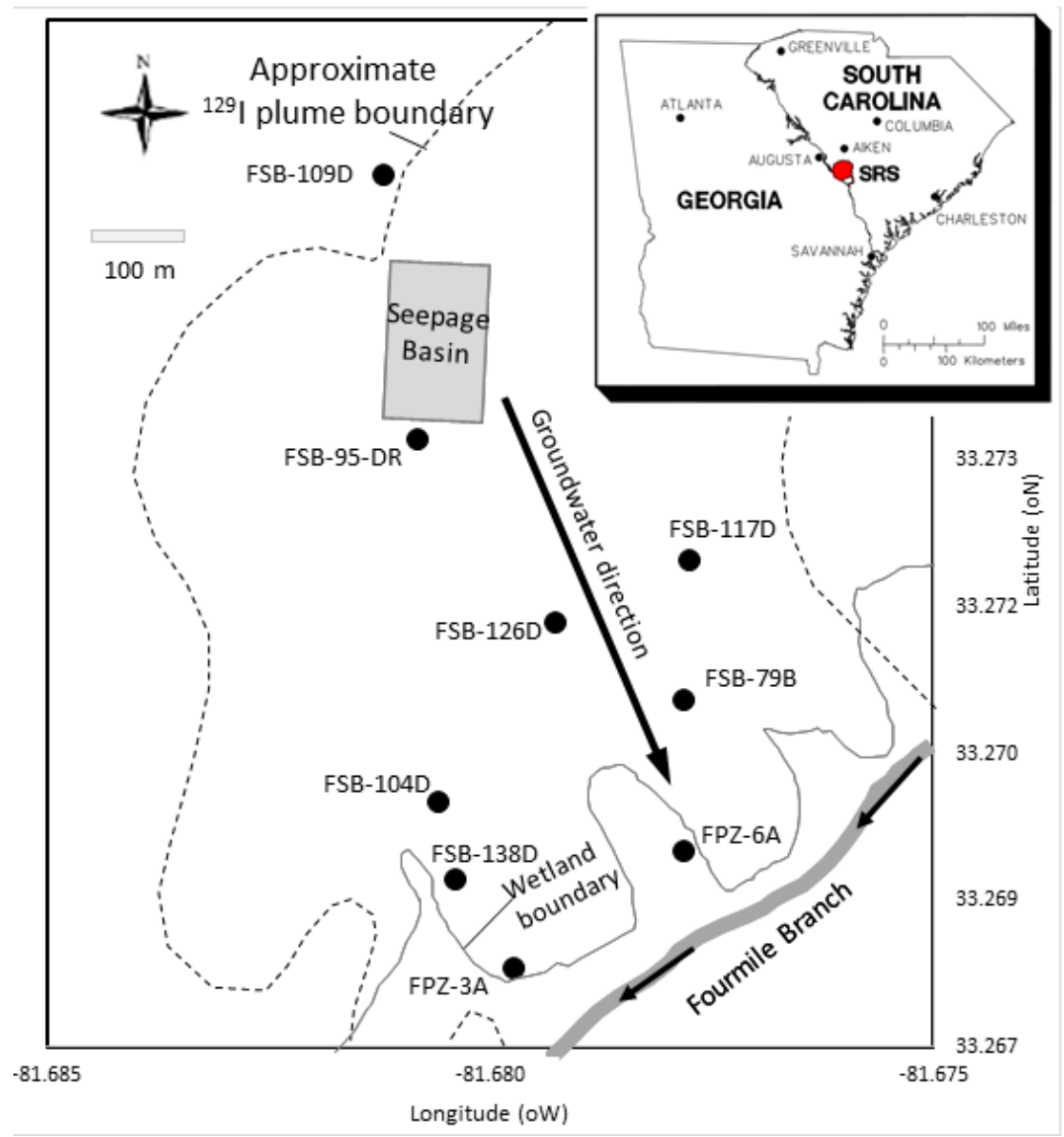

Schwehr et al., Fig. 1 


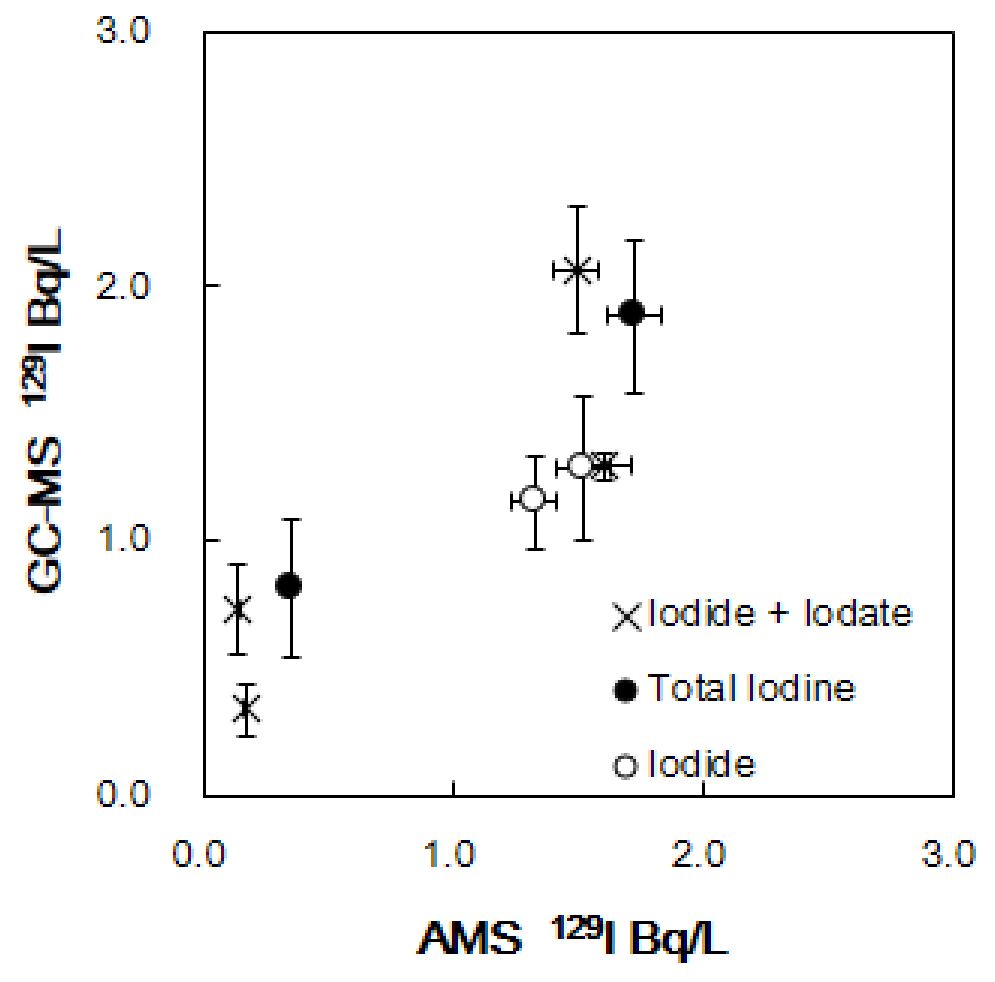

Schwehr et al., Fig.2 

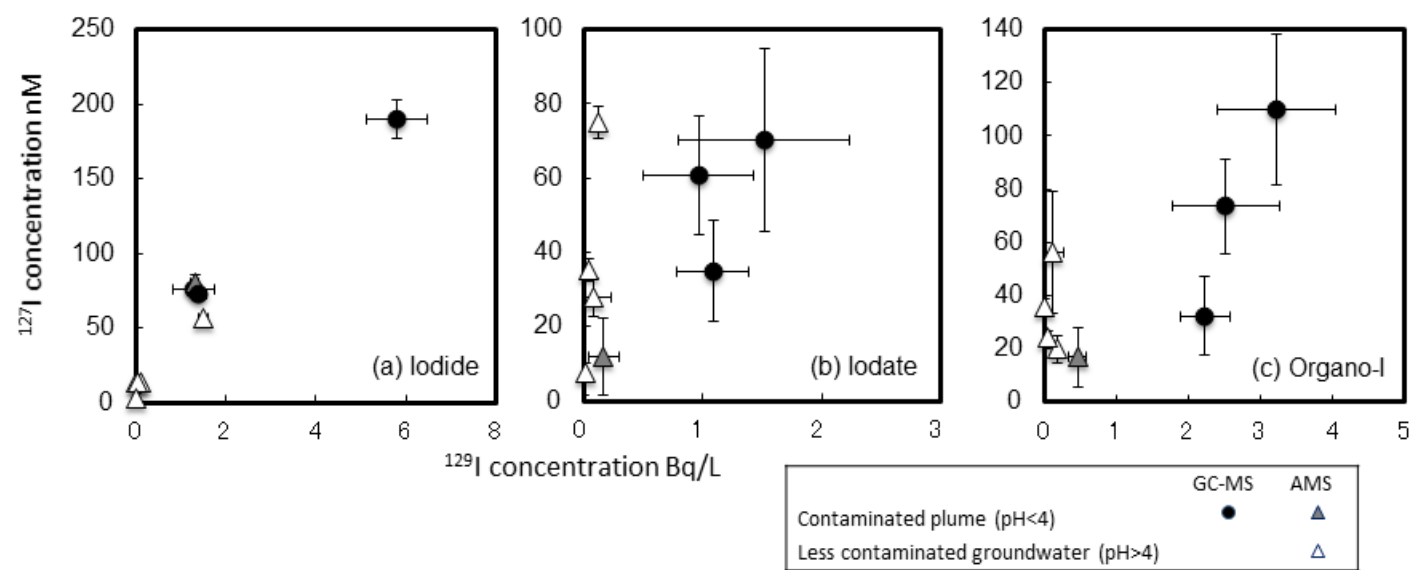

Schwehr et al., Fig.3 


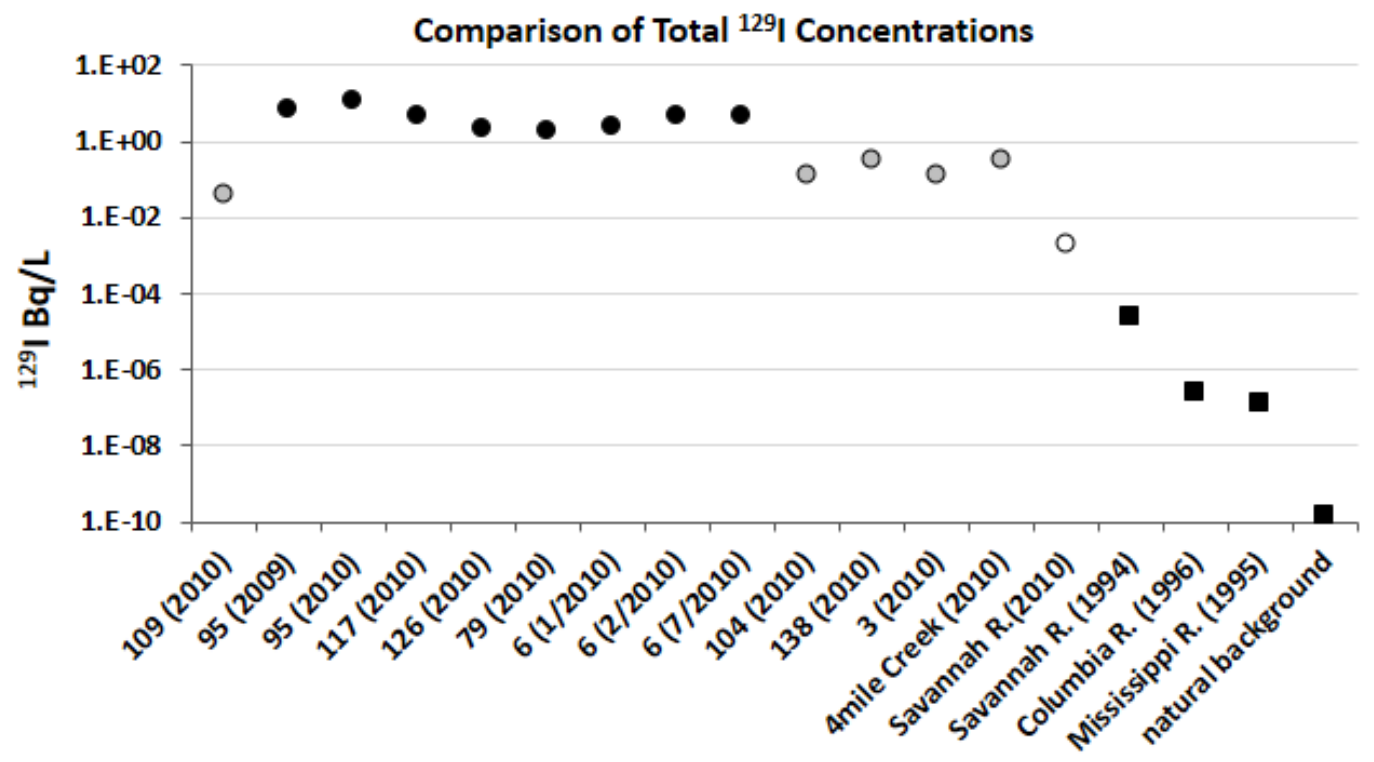

Schwehr et al., Fig. 4 